\title{
Impact of Awareness Rising Program on Corporate Social Responsibility Practice: an Analysis in Selected Bank
}

\author{
Mst. Rinu Fatema ${ }^{1} \quad$ Md. Habibur Rahman ${ }^{2 *} \quad$ Md. Hazrat $\mathrm{Ali}^{3}$ \\ 1.Department of Tourism and Hospitality Management, Noakhali Science and Technology University \\ 2.Department of management Information Systems, Noakhali Science and Technology University \\ 3.Department of Economics, Chowmuhuni Govt. S.A. College, Noakhali
}

\begin{abstract}
This paper interprets how to commercial banks practice corporate social responsibility in Bangladesh. This study represents focus on different Rules and regulations of Bangladesh. It also focuses on different awareness raising program of different organization arranged at different times. The standard chartered bank and the Daily Star arranged different awards to motivate different organizations towards Corporate social responsibility program. Different banks are now focusing on CSR activities as government has identified different sectors of CSR investment to get $10 \%$ tax rebate on Corporate Social Responsibility expenditure. Now, among different banks, the paper shows that the first priority of most of the bank is to invest in educational sectors. IBBL, Exim bank, DBBL, bank asia etc. invest only those sectors that provide tax rebate facilities to the organizations. The trend of CSR investment also showing increasing for the last few years with the increasing number of awareness rising program on corporate social responsibility.
\end{abstract}

Keywords: Corporate Social Responsibility, awareness, investment sectors, education, Community Development.

DOI: $10.7176 / \mathrm{EJBM} / 11-3-16$

\section{Introduction}

Corporate social responsibility in recent years has been a major trend in industrialized countries along with developing countries. The world famous many companies including the member of Fortune 500 invest in infrastructure, support or create projects tackling social, health or ecological issues and support good governs initiatives. Bangladesh is although newly experienced country regarding corporate social responsibility, there are some organizations both public and private organizations practices corporate social responsibility.

CSR is very much important from the both (either company or society) point of view. From the company's point of view, CSR helps company for long term survival. In addition, from the society's point of view, society will be benefited in many ways by the practices of CSR of the organizations. In fact, both parties will be benefited by CSR. Now-a-days management concerns managing financial and nonfinancial results with awareness of risk and maintenance of transparency. As a result, Corporate Social Responsibility (CSR) has possessed equal importance of corporate financial performance. Moreover, the aim of an organization is to create economic and social value to the society. At the same time the society always get advantages in different ways by the practices of CSR. This paper will try to describes the practices of CSR in Bangladesh with a comparative study and trend in CSR with the increment of the number of awareness rising program. In fact, most of the CSR studies conducted so far have been in the context of developed countries very few studies are available on the CSR practices in the developing countries (Belal). All of these studies were carried out in the contest of newly industrialized such as Malaysia and Singapore and the African countries such as - South Africa, Uganda (Belal). There are few detailed studies available in a South Asian context excepting the widely quoted one of Singh and Ahuja (1983), a case study on the Indian CSR by Hedge at (1997) and a very short study on Bangladeshi CSR by Belal (1999).

However here put emphasize on CSR practices of Dutch Bangla Bank and Exim Bank Ltd as to represent the picture of practices of CSR in Bangladesh.

\section{Review of the Literature:}

The role of business worldwide and specifically in the developed economies has evolved over the last few decades from classical, profit maximizing approach to a social responsibility approach, where businesses are not only responsible to its stockholders but also to all of its stakeholders in a broader inclusive sense. Because of global competitiveness and demand, the CSR practices and standards are being implemented in Bangladesh (Alimullah, 2006). Alam S.M.S et al. (2010) in a paper entitled "Corporate Social Responsibility of MultiNational Corporations in Bangladesh: A Case study on Grameenphone" pointed out that CSR is still an evolving concept that enables corporate executives to create and apply self-determined policies to best meet the needs and demands of its stakeholders.

Wise and Ali (2009) pointed out that CSR is still an evolving concept that enables corporate executives to create and apply self-determined policies to best meet the needs and demands of its stakeholders. Hackston and 
Milne (1996) used six categories: environment, energy, human resources, product and safety, community involvement, and other. A technique commonly used in social responsibility research to measure the significance of content is to count the number of words used to describe a particular issue (Hackston and Milne 1996). Furthermore, the nature and patterns of CSR vary between types of industry (Gray, Javed, Power \& Sinclair, 5 2001). Surveys of CSR practices in western countries reveal that companies place the greatest emphasis on disclosing human resource information such as employee numbers and remuneration, equal opportunities, employee share ownership, disability policies, and employee training (Gray et al., 2001).

Alam Shafiul, et al. (2010) pointed out that CSR is still an evolving concept that enables corporate executives to create and apply self-determined policies to best meet the needs and demands of its stakeholders. Here, it has remarked that the peculiar nature of CSR practices makes their cross-border management difficult. Achieving consistent CSR practices across global operations involves not only the transfer of the CSR practice, but also the transfer of its underlying value and meaning.

Azim et al. (2011) mentioned corporate social responsibility is not the only ethical dilemma that financial institutions face in an atmosphere of corrupt corporate practice. These institutions are also concerned with commitment for sustainable development. A well-functioning finance sector in any country can contribute directly to a healthy economy. Also cited, that CSR reporting of financial sector in Bangladesh is increasing and organization are concerned about the matter and significantly maintained in the annual report.

Belal A R (2001) made a study on different listed companies of Dhaka Stock Exchange (DSE) and found out that most of the companies made mandatory and non-mandatory information. He also noted that $51 \%$ companies did not disclose mandatory information. He has taken the study in the context of politics \& history, economic, socio-culture and regulatory \& institutional. Lastly, he made a comment that a number of companies are making social disclosure but the quantity of information disclosed is very low.

Khan $\mathrm{H}$ et al. (2010) stated in their report that most of the banks in the Bangladesh are not aware of CSR reporting and there is no such study has been taken to give strict result on the matter. They also showed that the practices of CSR reporting are increasing day by day in other regions like Europe, Asia, North America and Latin America

The CSR Triangle: According to Archie Carroll (2009) (as illustrated in his CSR pyramid adapted below), corporations need to satisfy the Economic ("be profitable") and Legal ("obey the law") dimensions as a priority before moving on to the Ethical ("be ethical") and Philanthropic ("be a good citizen") dimensions of society's expectations of business. The higher up the pyramid, the more discretionary the activities involved. The schematic diagram below presents a balanced platform for all four dimensions. Ceteris paribus, an increase in the impact of one dimension could reduce the importance or impact of the other dimensions. This provides an interesting insight into the possibility of a decrease in the opportunity available for organizations to act discretionarily in the interest of their stakeholders. Invariably, if financial institutions do not rise up to the situation and take control of the opportunity to demonstrate their responsibility to their stakeholder, then they are likely to witness an increase in regulation. If this happen, they will lose the benefits that CSR offers and this may impact on their economic performance as the costs of compliance increase.

Archie Carroll in1991 describes CSR as a multi layered concept that can be differentiated into four interrelated aspects - economic, legal, ethical and philanthropic responsibilities.

\subsection{Objectives of the Study}

The primary objectives of the study is to find out the trend of CSR investment with the increasing number of awareness rising program. The paper has also some secondary objectives:

$>$ To examine the status of CSR activities of different banks in Bangladesh.

To examine the comparative ratio of CSR investment of different banks.

$>$ To find out the sectors where banks contribute mostly for CSR investment.

$>$ To know the sectors where organizations get tax facilities and the involvement of banks for those sectors where get no tax rebate facilities.

\subsection{Methodology:}

The study of the paper involves the comparative analysis of CSR expenditure of different banks in different sectors like education, sports, social welfare etc. The paper highlighted the different sectors of corporate social responsibility to invest to get $10 \%$ tax rebate in Bangladesh. The paper focus on whether organizations invest only in the selected sectors mentioned in the SRO No. 270-Ain/2010, date 01.07 .2010 or every sectors equally. On the basis of the findings, the paper has made suggestion. We have conducted trend analysis and comparative analysis to find out the status with the increasing trend of aware rising program.

\subsection{Sampling of the Study:}

Four private commercial banks are selected here as sample of the study. These selected four private commercial 
banks are well established in Bangladesh, operated from a long period and popular enough everywhere in Bangladesh. These four banks comparatively contribute more on CSR than other banks and have enough information for further study.

\section{Theoretical framework of the Study \\ 3.1 The origin of CSR:}

The history of CSR is almost as long as that of companies. Concerns about the excesses of the East India Company were commonly expressed in the seventeenth century. There has been a tradition of benevolent capitalism in the UK for over 150 years.

\subsection{Social Responsibility:}

Definitely social responsibility includes the responsibility of social people, groups, societies, and business organization.

\subsection{Corporate social responsibility:}

Corporate social responsibility (CSR), also called corporate responsibility, corporate citizenship, responsible business and corporate social opportunity is a concept whereby organizations consider the interests of society by taking responsibility for the impact of their activities on customers, suppliers, employees, shareholders, communities and other stakeholders, as well as the environment.

ISO 26000 - International Guidance on Social Responsibility - ISO 26000:2010 provides guidance to all types of organizations, regardless of their size or location and has seven key themes and seven core principles. ISO 26000:2010 is intended to assist organizations in contributing to sustainable development. It is intended to encourage them to go beyond legal compliance, recognizing that compliance with law is a fundamental duty of any organization and an essential part of their social responsibility. It is intended to promote common understanding in the field of social responsibility and to complement other instruments and initiatives for social responsibility, not to replace them. ISO 26000:2010 is intended to provide organizations with guidance concerning social responsibility and can be used as part of public policy activities.

\subsection{Awareness rising Program on CSR :}

During the last five years several awareness programs are arranged by different organizations and different books and newsletters are published at different times encouraging involvement in CSR activities. These activities are related with:

1. CSR Champions: BEI and their CSR center's CSR round tables and newsletters have helped to raise the profile of CSR in Bangladesh. BGMEA and BKMEA as part of their charitable activities for their workers have implemented a significant number of CSR projects. International offices, international brands have included social compliance requirements in their codes of conduct for source factories.

2. CSR Awards: The national print media's reporting of CSR projects generally and of these Award Ceremonies in particular have also been influential in the development of CSR in Bangladesh. BAT Bangladesh has awarded Asia Responsible Entrepreneurship Award in 2014 under Green leadership by enterprise Asia. Different banks mainly Standard Chartered Bank and HSBC awarded CSR Awards for their good practices.

3. Tax Exemption: Under the SRO No. 270-Ain/2010, date 01.07.2010 is given 22 areas of CSR activities for enjoying $10 \%$ tax rebate. The areas includes (1) Donation to organizations engaged in clean water management (2) Donations to organizations engaged in afforestation ; (3) Donations to organization engaged in beautifications of cities; (4) Donations to organization engaged in waste management; (5) Donations for redressing the hardships caused by natural calamities; (6) Donations to organizations engaged in establishment and management of old persons home; (7) Donations to organizations engaged in the welfare mentally or physically handicapped; (8) Donations to educational institutions run for the purpose of education of rootless people; (9) Donations to organizations engaged in projects on accommodation for the slum dwellers; (10) Donations to social organizations engaged in publicity of movements relating to women's rights and anti-dowry practices; (11) Donations to organizations engaged in feeding and clothing and sheltering and rehabilitation of orphan/rootless children; (12) Donations to organizations engaged in research on independence war, regaining and expansion of the consciousness of the independence war and the act of honorable living of the freedom fighters; (13) Donations to organizations engaged in health some situation in Chittagong Hill Tracts, char areas and areas surrounding breaking up of bank of river; (14) Grants to organizations engaged in treating cleft lips, cataract, cancer, and leprosy; (15) Grants the organizations engaged in treating acid victims; (16) Donations to hospitals engaged in providing free medical treatment to poor patients and specialized for developing the quality of treatment, such as cancer, liver, kidney, 
thalassemia, eye and cardio; (17) Donations to organizations distributing freely at the level of use of birth -control products with a view to solving the population problem and to conduct camps for voluntary sterilization; (18) Grants to Public Universities; (19) Expenditure incurred through educational institutions recognized by Government for providing technical and vocational education for meritorious poor students; (20) Money invested in establishing lab for providing training on computer or information technology and in establishing infrastructure or in purchasing educational materials for implementing English education in public /private educational institutions (under Monthly Pay Order or MPO); (21) Donations to organizations engaged in providing technical and vocational training to unskilled or semi-skilled labor for export of human resources; and (22) Donations to organizations involved with infrastructure of sports and provision of training at national level (Du S, 2010; 12(1)).

4. Seminars, workshop and roundtables: Different organizations have been offering CSR discussions and events for the last five years. Some of the events were organized by universities e.g. by university of Chittagong and Daffodil University. Donor agencies, embassies, companies and banks are sponsoring in the CSR events. DFAIT Canadian trade commissioner service, UNDP, the embassy of the kingdom of the Netherlands and giz many other agencies sponsor seminar programs. The BEI series of CSR round tables and publication of a CSR newsletter and CSR center is now working as a think tank for CSR in Bangladesh.

5. Books about CSR in Bangladesh: Corporate Moral Responsibility, Waking with Bengal tiger, Corporate social responsibility in developing countries, A CSR guide for entrepreneur and Factory managers, CSR good for business good for Bangladesh etc.

\section{Analysis:}

Dutch Bangla Bank Limited and Exim Bank Limited plays a vital role in the society by performing its CSR activities. For providing the most courteous and efficient services in every aspect of the business both the bank will consider CSR activities. To be innovative in the development of new banking products and services it plays a significant role. Education, health, disaster management, sports, social development, social awareness etc. are the CSR activities of these banks. DBBL has been awarding scholarship to the meritorious students in need of financial aid since its beginning. Considering the number of such students is huge the Bank has planned to increase the scholarship number to an impassable level of 30,000 involving an amount of Taka 1.02 billion annually from the year 2017.

\section{CSR Expenditure trend of DBBL and Exim Bank}

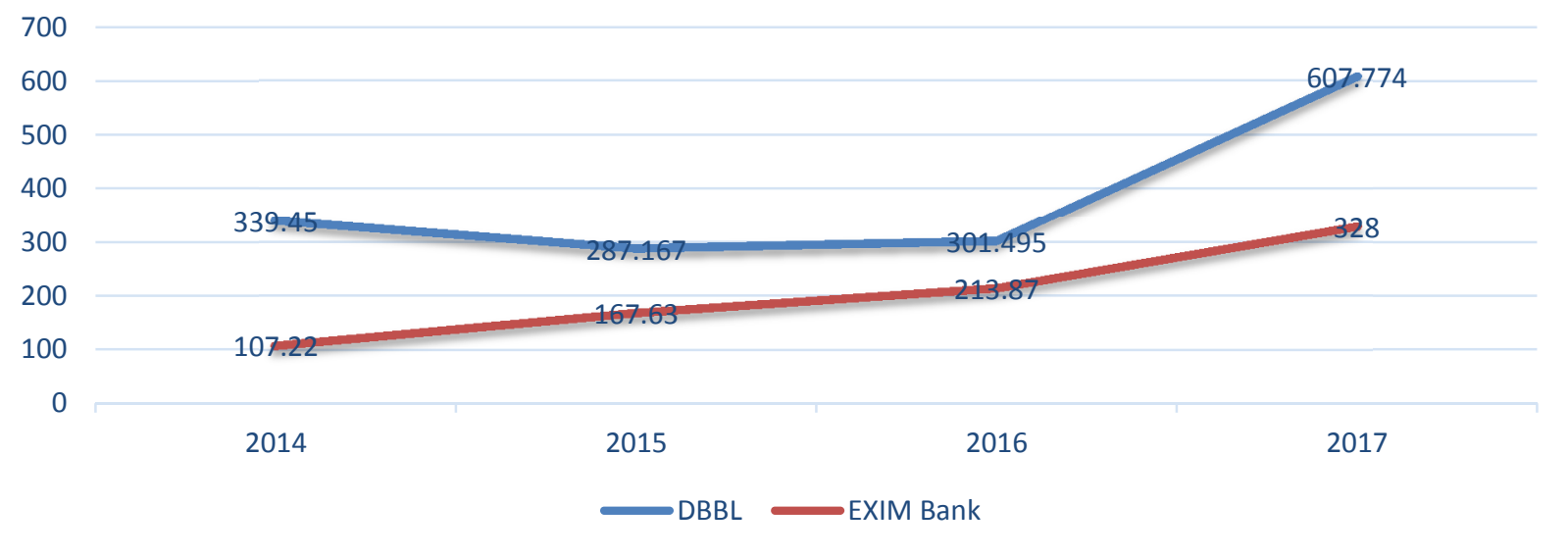

Figure 01: The contribution of CSR activities of DBBL and Exim Bank Ltd.

In the figure01, we see that in 2014 DBBL has higher investment than 2015 but increases after that as awareness rising campaign conducted by different organization has increased for the last five years. The figure also shows that Exim bank has increased investment in CSR activities for the last 4 years when awareness rising campaigns also increased.

In year 2017 we can see in educational sector DBBL have contributed $46 \%$, in health $37 \%$, in social development $4 \%$, in disaster management $10 \%$ and rest are contributed in other sectors. On the other hand, in 2017 Exim Bank Limited contributed highest (47\%) at education sector out of their total contribution. They also contributed health sector, social development sector and disaster sector $15 \%, 13 \%$ and $7 \%$ respectively. Exim Bank ltd. also contributed 13\% amount of total for creating social awareness. These banks are working on the educational expansion by linking the allowing scholarship, educational infrastructures development as per the 
necessity of educational development. Both the Banks contribute a lot for improving the health sector. Disaster management or catastrophe management is very important element of CSR practices in Bangladesh. Every year our country is facing many problems for natural calamity. For these reason Dutch -Bangla Bank Limited and Exim Bank Limited concentrate in these sector and try to expand its CSR activities. Both the Banks also contribute a huge amount for creating the social awareness specially assisting, the awareness level of reducing man made problems, social problems, cultural development etc. The subsidiary expenses of the CSR action are to green environment making, infrastructures development helping, poor people helping, etc. both banks amounted huge amount every year to make it and care of CSR activities.

Interpretation: From the above figure we can see that in 2014-2017 DBBL contribution was Tk. 1535.886 million. On the contrary in 2014-2017 Exim bank Ltd. donated Tk. 816.72 million. The contribution of DBBL has increased by $118.13 \%$ from base year 2014. Again the contribution of Exim bank Ltd. has increased by 205.91\% from base year 2014. The Percentage (\%) of contribution of Exim bank Ltd. is greater than DBBL, pictorial presentation given below in figure:

\subsection{CSR Contributions of Commercial Banks in Different Areas:}

As per Bangladesh Bank's Review of CSR activities of financial sector in 2017, total annual direct CSR expenditure of banks increased by Tk. 1,484.80 million than the previous year.

\begin{tabular}{|c|c|c|c|c|}
\hline Year & $\mathbf{2 0 1 4}$ & $\mathbf{2 0 1 5}$ & $\mathbf{2 0 1 6}$ & (In Million Taka) \\
\hline CSR Expenditure & $2,188.33$ & $3,046.69$ & $4,471.49$ & 5956.29 \\
\hline
\end{tabular}

Source: Bangladesh bank annual report for 2014, 2015, 2016 and 2017

Table 01: Overall investment by different banks in CSR

From the table 01, we have come to know that the total corporate social responsibility from 2014 to 2017 are in increasing trend that are expended by different banks in CSR activities. With the increasing CSR awareness rising campaign, different banks are increasing their contribution in different sectors. Different award, Round table conference has been accelerating awareness to corporate social responsibility and also increasing the amount of investment in corporate social responsibility.

4.2 Comparative Contribution to CSR Activities by Five different banks -2017:

\begin{tabular}{|l|c|c|c|c|c|c|l|l|l|l|}
\hline \multicolumn{1}{|c|}{ Sectors } & DBBL & $\mathbf{( \% )}$ & EBL & $\mathbf{( \% )}$ & \multicolumn{1}{c|}{ IBBL } & \multicolumn{1}{c|}{ B } & BAL & \multicolumn{1}{c|}{ \% } & MBL & \% \\
\hline Education & 279.576 & 46 & 170.56 & 52 & 83.8 & 27.10 & 18.44 & 26.55 & 13.8 & 16 \\
\hline Health & 224.865 & 37 & 52.48 & 16 & 39.75 & 12.86 & 05.74 & 08.26 & 26.8 & 31 \\
\hline Social Development & 24.309 & 4 & 45.92 & 14 & 8.24 & 2.67 & 0.47 & 0.68 & 1.8 & 02 \\
\hline Disaster Management & 60.774 & 10 & 26.24 & 8 & 87.93 & 28.44 & 21.55 & 31.03 & 17.5 & 20 \\
\hline Social Awareness & 6.077 & 1 & 13.12 & 4 & 12.48 & 4.04 & 1.23 & 1.77 & 7.77 & 02 \\
\hline sports & 3.041 & .5 & 3.14 & 1 & 1.61 & 0.52 & 1.23 & 1.77 & 2.4 & 03 \\
\hline Miscellaneous & 9.114 & 1.5 & 16.54 & 5 & 75.38 & 24.38 & 20.79 & 29.94 & 24.3 & 26 \\
\hline Total & 607.744 & 100 & 328.23 & 100 & 309.19 & 100 & 69.45 & 100 & 94.37 & 100 \\
\hline
\end{tabular}

Source: Annual Report 2017.

Table 02: Comparative Contribution to CSR by d-2017ifferent banks in 2017.

In the year 2017, DBBL contributed Tk. 607.744 million and on the contrary Exim Bank Ltd. contributed Tk. 328.23 million in CSR activities where DBBL 46\% and Exim Bank Ltd. So both of Bank DBBL and Exim Bank Ltd. has been playing a responsible role in implementing social and philanthropic programs to help disadvantaged people of the country. 


\section{Sectorwise Investment of different banks}

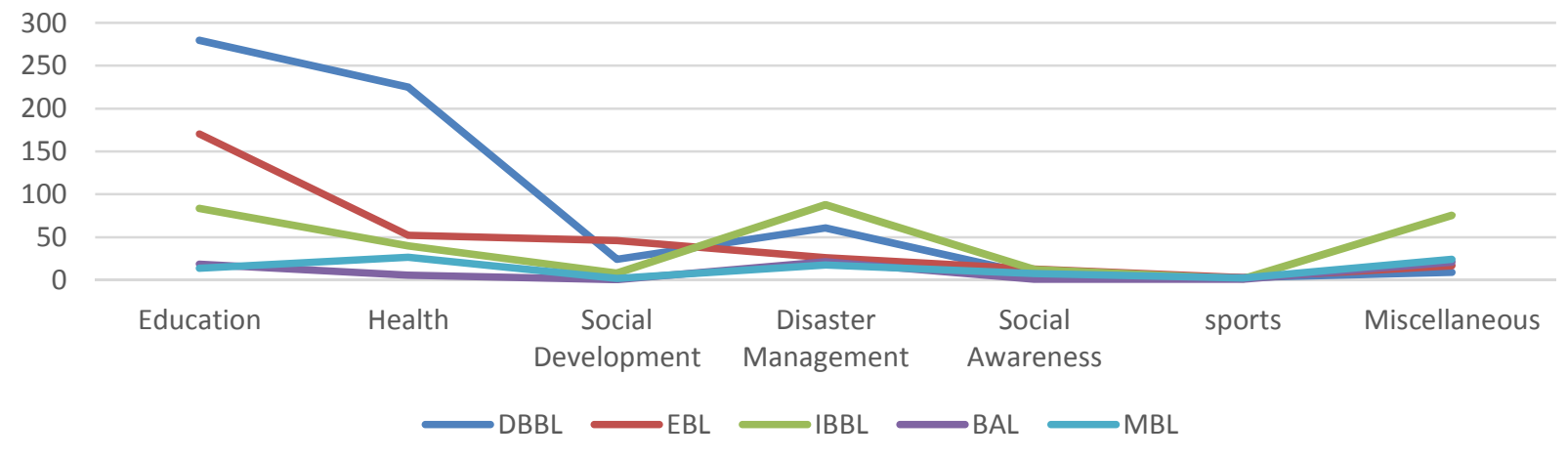

Figure 02: Sector wise Investment of different banks

In the figure 02, we find that DBBL make highest investment in Education where IBBL made in Disaster management. DBBL and Exim bank are forwarded in investment of education and health sector. The figure shows that DBBL and Exim banks are the top in terms of CSR activities and investment. It is also found that all banks are investing in the sectors that provide tax rebate facilities.

\section{Findings and Analysis}

This paper has found following findings through analysis of collected information \& data. The contribution on CSR by both banks has increased day by day. The total contribution of both bank was Tk. 2352.606 million from 2014 to 2017.The contribution of DBBL in different sectors in 2017 was Tk. 607.744 million and Exim Bank contribution was Tk. 328.23 million. DBBL spends $46 \%$ of total contributions at education sector in 2017. On the other hand, Exim Bank Ltd. contribution at education sector was 52\% of total contribution. In $2017 \mathrm{DBBL}$ contributed $46 \%$ in education sector, $37 \%$ in health sector, $4 \%$ in social development, $4 \%$ in disaster management and 3\% to others. In 2017 Exim Bank Ltd. contributed 47\% in education sector, 15\% in health sector, $13 \%$ in social development, $7 \%$ in disaster management and $13 \%$ for social awareness and $5 \%$ for miscellaneous sectors. IBBL is the leading organizations in the banking industry making highest contribution in the disaster management. Comparatively DBBL has greatest contribution in CSR activities than Exim Bank Ltd. Considering education is most important tool both bank places much contribution to education sector. The analysis shows that most of the banks are investing in those sectors that are related to prove Tax rebate facilities. Besides that, they have very few investments. So, government should find out more sectors to be provided tax rebate facilities and organization should also invest in CSR activities that brings welfare of the society.

\section{Recommendations}

In the fast evolving world, it is very necessary for each and every organization to build a strong presence in the market by maximizing profit margin by satisfying their customers as much possible. After completing study, we think the following recommendations will help to perform CSR activities more effectively: Customer is the key factor for private commercial bank so banks must have increase their CSR activities to satisfy their customers. For sustaining on market banks should maximize their contribution on CSR and try to lead new ideas to expand their present CSR contribution. Bank should use of promotional tools such as advertising, sales promotion, public relation and publicity about their CSR contribution. CSR contribution should be reached at marginal level of society. Both DBBL and Exim Bank Ltd. mainly contribute on education sector, but they should focus other sectors (Environment and Disaster management) also. Comparatively Exim Bank has less contribution than DBBL, so they should increase their contribution to compete with others. The contribution on CSR activities of DBBL is comparatively less in according to their business level. As a banker of all banks, Bangladesh Bank should assign a more effective regulatory body for supervision of private bank's CSR program. Different awareness rising program can also be introduced to motive organizations and create awareness for increasing CSR investment. Government should take more effective program for raising public awareness about CSR program. All private commercial banks should introduce a combined program for better expansion of CSR activities.

\section{Conclusion}

The CSR activities of bank is increasing day by day which leads to increase competition as well. All the Commercial Banks are offering almost the same products and services and their operation system is almost same. So people choose their bank according to their satisfaction and needs. And they will prefer the bank of which 
service is easily accessible and understandable. If more company come forward to contribute to the society like DBBL, IBBL, Bank Asia Ltd., Mercantile bank Ltd and Exim Bank Ltd, it will help to create their social branding as well as helping the society. DBBL is a pioneer in Corporate Social Responsibility because the idea of CSR is vastly expanded by DBBL at first. Moreover, DBBL is establishing goodwill through the CSR. On the contrary Exim Bank Ltd. has huge reputation for contributing on CSR activities. Both the banks play vital role for society development.

This study was attempted to explain an overall outlook of the Corporate Social Responsibility (CSR) undertaken by the different commercial banks in Bangladesh. Bank having the highest profit or assets may not be the one who actively engages with various types of stakeholders. It may be a matter of determination and banks' care for the whole community and society and all stakeholders. Therefore, the trend of having CSR practices is unavoidable. However, highest effort has been given to achieve the specific objectives of the program.

Finally, Finally, CSR contributions are increasing day by day by commercial banks of Bangladesh with the increasing number of CSR awareness rising program. Though maximum private commercial banks are still lagging behind in CSR contribution, however if all the private commercial banks give proper attention to this important issue and contribute toward CSR activities it will play a significant role in mitigating of social obligations. Governments should consider including CSR requirements in Companies Ordinance or Banking Ordinance in order to encourage banks to be more socially responsible.

\section{References}

Du S, B. C. (2010; 12(1)). Maximizing business returns to corporate social responsibility (CSR): the role of CSR communication. International Journal of Management Reviews, 8-19.

Hussain B., and M. Hussain (2005), "Corporate Social Responsibility: Do Customers Get What They Expect?" Journal of Business Studies, Southeast University, ISSN- 1815- 3267 Vol 1 No. 1, July-December.

Md. Arif Hasan (2013) "Corporate Social Responsibility in the Banking Sector: A Comparative Study on Some Commercial Banks in Bangladesh", University Journal of Business and Economics, Vol. 7, No. 1.Khan, A R, Bank Management; A fund emphasis, (1 ${ }^{\text {st }}$ ed.-2008), Dhaka, Ruby Publications.

Saha \& Chowdhuray, "Role of Commercial Bank in Development Financing in Bangladesh" Bank Parikrama (March 2009) Vol. XXV.

Lance M. (2001). What do we mean by corporate social responsibility?Corporate Governance, 1(2), 16-22.

Mandhachitara R., \& Poolthong Y. (2011). A model of customer loyalty and corporate social responsibility. Journal of Services Marketing, 25(2), 122-133. (http://dx.doi.org/10.1108/08876041111119840)

Masud A. K.,"CSR practices of private commercial banks' in Bangladesh: A comparative study" MPRA paper no. 35496 online at http://mpra.ub.uni-muenchen.de/35496, 2011

Azim M. I., Ahmed S. and Islam M. S.,"Corporate Social Reporting Practice: Evidence from Listed Companies in Bangladesh", Journal of Asia Pacific Business, Vol. 10 No. 02, 2009, 130-145

Sharma N., "CSR Practices and CSR Reporting in Indian Banking Sector" International Journal of Advanced Economics and Business Management Vol. 1 No. 2, 2011, Pp. 58-66

European Commission. (2011). Communication from the Commission to the European Parliament, the Council, the European Economic and Social Committee and the Committee of the Regions - A Renewed EU Strategy 2011-14 for Corporate Social Responsibility. Available at http://ec.europa.eu/ enterprise/ policies /sustainable-business/corporate-social- responsibility

Carroll, A.B. (1999). Corporate Social responsibility: evolution of a definition and construct, Business \& Society, 38(3), 68-95

Jamali, D., Mirshak, R. (2007). Corporate social responsibility (CSR): Theory and practice in a developing country context, Journal of Business Ethics

Rana, M., M., Kalam, A., \& Halimuzzaman, M. (2012). Corporate Social Responsibility (CSR) of Dutch-Bangla Bank Limited: A Case Study. Bangladesh Research Publications Journal, 7(3), 241-247

http://www.wbcsd.org/about/organization.aspx

Miyan M Alimullah (2006), "Dynamics of Corporate Social Responsibility -Bangladesh Context" Journal of AIUB Bangladesh, August, Vol.3, No. 1, Pp. 13

$32, \mathrm{com} . \mathrm{bd} / \mathrm{url}$ ? $\mathrm{sa}=\mathrm{t} \& \mathrm{rct}=\mathrm{j} \& \mathrm{q}=\&$ esrc $=\mathrm{s} \&$ source=web\&cd=1\&ved=0CCoQFjAA\&url=http $\% 3 \mathrm{~A} \% 2 \mathrm{~F} \% 2 \mathrm{Fwww} . \mathrm{re}$ searchsea.com $\% 2$ Fhtml $\% 2$ Fdownload.php $\% 2$ Fid $\% 2$

Yeung S, "The Role of Banks in Corporate Social Responsibility" Journal of Applied Economics and Business Research, ( JAEBR) Vol.1 No. 2, 2011, Pp.13-115.

Hussain B., and M. Hussain (2005), "Corporate Social Responsibility: Do Customers Get What They Expect?" Journal of Business Studies, Southeast University, ISSN- 1815- 3267 Vol 1 No. 1, July-December.

Md. Arif Hasan (2013) "Corporate Social Responsibility in the Banking Sector: A Comparative Study on Some Commercial Banks in Bangladesh", University Journal of Business and Economics, Vol. 7, No. 1.Khan, A 
R, Bank Management; A fund emphasis, (1 ${ }^{\text {st }}$ ed.-2008), Dhaka, Ruby Publications.

Saha \& Chowdhuray, "Role of Commercial Bank in Development Financing in Bangladesh" Bank Parikrama (March 2009) Vol. XXV.

Lance M. (2001). What do we mean by corporate social responsibility? Corporate Governance, 1(2), 16-22.

Mandhachitara R. \& Poolthong Y. (2011). A model of customer loyalty and corporate social responsibility. Journal of Services Marketing, 25(2), 122-133. (http://dx.doi.org/10.1108/08876041111119840)

\section{Websites}

i) Bangladesh Bank (http://www.bangladeshbank.org)

ii) Web Site of Dutch-Bangla Bank Limited (http://www.dbbl.com.bd)

iii) Web Site of Exim Bank Limited

iv) http://en.wikipedia.org/wiki

\section{Others}

i) Annual Reports of Dutch-Bangla Bank Limited

ii) Annual Reports of Exim Bank Limited

iii) Statement of Affairs-2014, 2015, 2016\& 2017 of DBBL and Exim Bank Ltd. 